\title{
Açık Liderliğin Kamu Hizmeti Motivasyonu Üzerindeki Etkisi: Sağlık Sektöründe
} Bir Uygulama

\section{The Impact of Open Leadership on Public Service Motivation: A Practice in the Health Sector}

Fuat Korkmazer ${ }^{\mathrm{a}^{*}}$

${ }^{a}$ Dr. Öğr. Üyesi, Muş Alparslan Üniversitesi, Sağlık Bilimleri Fakültesi, Sağlık Yönetimi Bölümü, 49250, Muş/Türkiye. ORCID: 0000-0002-2734-7309

\section{MAKALE BİLGISİ}

Makale Geçmişi:

Başvuru tarihi: 31 Aralık 2020

Düzeltme tarihi: 03 Şubat 2021

Kabul tarihi: 09 Şubat 2021

\section{Anahtar Kelimeler:}

Liderlik

Açık Liderlik

Kamu Hizmeti Motivasyonu

\section{ARTICLE INFO}

\section{Article history:}

Received 31 December 2020

Received in revised form 03 February 2021

Accepted 09 February 2021

\section{Keywords:}

Leadership

Open Leadership

Public Service Motivation
ÖZ

$\mathrm{Bu}$ araştırmada açık liderlik algısının çalışanların kamu hizmeti motivasyonu düzeyleri üzerindeki etkisini araştırmak amaçlanmıştır. Veri toplamada Açık Liderlik Ölçeği ve Kamu Hizmeti Motivasyonu Ölçeğinden yararlanılmıştır. Araştırma bir kamu hastanesinde çalışan 229 sağlık çalışanına uygulanmıştır. Araştırmada elde edilen verilerin analizinde SPSS istatistik programından yararlanılmıştır. Araştırma sonucunda açık liderlik ile kamu hizmeti motivasyonu arasında orta düzeyde, pozitif ve anlamlı bir ilişki tespit edilmiştir. Ayrıca açık liderliğin çalışanların kamu hizmeti motivasyonu düzeyleri üzerinde anlamlı bir etkisi olduğu sonucuna ulaşılmıştır.

\section{A B S T R AC T}

In this study, it is aimed to investigate the effect of open leadership perception on the level of public service motivation of employees. The Open Leadership Scale and the Public Service Motivation Scale were used in data collection. The research was applied to 229 healthcare workers working in a public hospital. SPSS statistical program was used to analyze the data obtained in the study. As a result of the research, a medium level, positive and significant relationship was found between explicit leadership and public service motivation. In addition, it was concluded that open leadership has a significant effect on employees' level of public service motivation.

\section{Giriş}

21. yüzyıl becerilerine ulaşabilmek için işletmelerde çalışanların yeterliliklerinin önceden belirlenen hedefler doğrultusunda geliştirilmesi ve desteklenmesi gerekir. Bu kapsamda sağlık kurumları yöneticileri, sağlık çalışanları, hastalar ve yakınlarının işbirliği içerisinde hareket ederek topluma uygun sağlık hizmetleri oluşturmaları önem arz etmektedir.
Ekip ruhu ile yapılacak çalışmalara ihtiyacın arttığı günümüzde sağlık kurumları önceden belirlenen hedeflere ulaşabilmek için bu hedeflere yönelik çalışmaları destekleyip yönlendirecek yöneticilere ihtiyaç duymaktadır. Bir kurumun yönetilmesinde her zaman ve her yerde geçerli olan en iyi yöntem olmadığı için sağlı kurumları yöneticilerinin de içinde bulundukları toplum hakkında yaptıkları değerlendirmeler 1şığında grubun gücünü kullanması beklenmektedir.

\footnotetext{
* Sorumlu yazar/Corresponding author e-posta: f.korkmazer@alparslan.edu.tr
} 
Liderlik ile ilgili günümüzde ortaya çıkan yeni liderlik kavramları giderek daha da önem kazanmaktadır. Liderlerden beklenen önemli özelliklerin başında işletmelerin amaçlarına ulaşmasında başrol üstlenmeleri gelmektedir. Sağlık kurumlarında liderlik rolünü üstlenen yönetici özelliğine sahip liderlerin birçok farklı niteliği barındıran özelliklere sahip olması gerekmektedir. Açık liderlik sahibi olan yöneticiler, sağlık kurumlarında samimi bir kişilerarası iletişim bağı geliştirerek fonksiyonel yönetime odaklanmış liderler olacaklardır. Bu kapsamda farklı pek çok liderlik çeşidi tanımında yer alan açıklık ifadesi liderlerde bulunması gereken önemli bir özelliktir (Polat ve Arabac1, 2014: 36).

İş motivasyonu birey ve kurum performansının temel belirleyicisi şeklinde görülmektedir. Motivasyonu sağlanmış çalışanlar kurumların kaliteli hizmet sunumu için temel unsurlardandır. Bu kapsamda, sağlık kurumları yöneticileri çalışanların motivasyonuna etki eden faktörlere önem vermişlerdir. Kamu Hizmetleri Motivasyonu (KHM) kuramı, konuya detaylı ve tutarlı olarak yaklaşmayı amaçlamaktadır. Bu kuram, farklı motivasyon faktörlerini birbiriyle uyumlu hale getirmeye çalışmaktadır. Başka bir ifadeyle kuram, kamu kurumlarında çalışanların farklı seviyede iş motivasyonu sahibi olma nedenini içsel ve dışsal etmenleri ile birlikte değerlendirerek açıklamaktadır (Anderfuhren-Biget vd., 2010: 213).

$\mathrm{Bu}$ çalışmada işletmede yönetsel açıklığa dayalı bir liderlik türü olan açık liderlik ve kamu hizmeti motivasyonu ilişkisi üzerinde durulmuştur. Araştırmada öncelikle açık liderlik ve kamu hizmeti motivasyonu ile ilgili kısaca kavramsal bir çerçeve çizilmiştir. Ardından sağlık sektöründe faaliyet gösteren bir kamu hastanesinde yapılan uygulama ile ilgili bilgilere yer verilmiştir. Sonuç kısmında ise açık liderliğin sağlık sektöründeki yöneticiler tarafindan kullanılabilirliği ve çalışan motivasyonuna etkileri ile ilgili sonuçlara değinilmiştir.

\section{Kavramsal Çerçeve}

\subsection{Açık Liderlik}

Liderlik kavramına bakış sürekli değişmekte ve bu değişim sürmektedir. Günümüz liderlerinin taşımaları gereken birçok özelliğin yanı sıra, açık bir lider olmaları da gerekmektedir. Açık liderlik kavramı oldukça yeni olduğu için konu ile ilgili literatürde yeteri kadar çalışmaya rastlanmamaktadır. Charlene Li (2010) açık liderliği, "İnsanların hedeflere ulaşmak için bağlılıklarını teşvik ederken, kontrolde olma ihtiyacından vazgeçecek güven ve alçakgönüllülüğe sahip olmak" biçiminde tanımlamaktadır. $\mathrm{Li}$, açık liderliğin yöneticilerin başarılı olabilmesi için kontrol çabalarından vazgeçmeleri gerektiğini vurgulamaktadır. Yani açık liderler başarılı olabilmek için kontrole yönelik davranışlardan ziyade, özgüven sahibi olmak ve belirli hedeflere ulaşmak için çalışanlara, kendilerini işlerine adamaları konusunda cesaret vermelidir. Açık liderlerin bu süreci önemle işletmesi gerekmektedir. Açık liderler bu süreci kendilerinde bulunması gereken özgül açık liderlik özellikleriyle gerçekleştirmektedir (Li, 2010: 14).

Açık liderler, işlerinde çalışanlar ile aralarında güven temeline dayalı çeşitli ilişkiler kurmaya yönelik davranışlar geliştirme amaçlı eylemleri ilke edinirler. Açık liderlerin temelde bağımsız düşünebilmesi, işbirliğine yatkın ve iyimser olması beklenmektedir. Açık liderler yeni ilişkileri teşvik etmekte ve bu yeni ilişkilerin nasıl işlediğini anlamak ve yönetmek için bazı kurallara ihtiyaç duymaktadır. Bunlar (Li, 2010: 14-15):

1- Müşterilerin ve Çalışanların Gücü Olduğuna Saygı Duyulmas1: Liderler, müşteriler ve çalışanların gücü olduğunu kabul ederek bu güce saygı duyduğunda, onlarla gerçek ve daha dengeli bir ilişki kurmaya başlayabilir. Bu zihniyet olmadan liderler, müşterileri ve çalışanları değiştirilebilir kaynaklar olarak görmeye ve onlara bu şekilde davranmaya devam edecektir.

2- Güven Oluşturmak İçin Sürekli Paylaşım Yapılması: Başarılı bir ilişkinin özü güvendir. Güven, genellikle insanlar yapacaklarını söyledikleri şeyi yaptıklarında oluşmaktadır. Ancak güven, günümüzün giderek artmakta olan sanal ve etkileşim halindeki ortamlarında, günlük konuşma kalıplarından oluşmaktadır. İnsanların düşüncelerini, faaliyetlerini ve endişelerini paylaşması güveni tesis etmekte ve bu güven de başarılı bir ilişki ile sonuçlanmaktadır.

3- Merak ve Alçakgönüllülüğün Desteklenmesi: Birinin ne yaptığı ve onun için bir şeyin niçin önemli olduğu konusundaki merakını ifade etmek, kişiyi söylemek istedikleri ile dengeli bir şekilde paylaşmaya devam eder. Merakın doğal olarak gelişmesi alçakgönüllülüktür, bu da lidere hala öğrenecek çok şeyinin olduğunu kabul etmesi ve aynı zamanda yanıldığını kabul etmesi için entelektüel bütünlük vermektedir.

4- Açık Olmanın Hesap Verebilir Tutulması: İlişkilerde hesap verebilirlik iki yönlü bir yoldur. Hesap verebilirlik, ilişkideki beklentileri ve karşılanmadıkları takdirde sonuçları netleştirmektedir. Aynı şekilde, çalışanlara faaliyetler hakkında yorum yapma yetkisi verildiğinde çalışanlar bunu kötüye kullandığında, sonuçlardan sorumlu olacaklarını bilmeleri gerekmektedir.

5- Başarısızlığın Affedilmesi: Hesap verebilirliğin doğal sonucu affetmektir. İlişkilerde işlerin ters gitmesi normaldir. En sağlıklı liderler bu durumlarda kin ve suçlamayı geride bırakmalıdır. $\mathrm{Bu}$ durum, başarısızlığın kabul edildiği anlamına gelmemekte, hataları tanımak ve anlaşılır kılmaktadır.

Kısacası açık liderler kurum içerisinde güven duygusunu geliştirmeli ve bunun öneminin farkında olmalı, bunu sürekli paylaşımlarla desteklemeli ve bir hesap verebilir olma felsefesiyle hareket etmelidir. Her türlü merak ve alçakgönüllülüğe destek vermeli, gerekirse başarısızlıkları bağışlama erdemine sahip bir liderlik tutumu geliştirmelidir (Polat, 2015: 39).

\subsubsection{Açık Liderliğin Unsurları}

Bu bölümde açıklığın her bir unsuru veya bileşeni içinde, açık olmanın ne anlama geldiği üzerinde durulacak ve daha anlaşılır hale geldikçe gerçekte nelerden vazgeçildiği de anlaşılacaktır. Açık olmanın on unsuru bulunmaktadır ve bu unsurlar iki geniş kategoriye ayrılmaktadır. Aşağıdaki tabloda bu unsurlar ele alınmıştır (Li, 2010: 21-43). 
Tablo 1. Açıklığın On Unsuru

\begin{tabular}{|l|l|}
\hline Bilgi Paylaşımı & Karar Verme \\
\hline Açıklama & Merkezileştirilmiş karar \\
Güncellenme & verme \\
Konuşma & Demokratik karar verme \\
Açık Mikrofon (Katılımı teşvik etme) & Uzlaşma (Kendi kendini \\
Kitle kaynak kullanımı & yönetme) \\
Platformlar & Dağıtılmış karar verme \\
& \\
\hline
\end{tabular}

Kaynak: Li, 2010: 22

İnternetin yaygın bir şekilde kullanılmasıyla başlayan ve sosyal teknolojilerle ilerleyen yeni teknolojilerin ortaya çıkmasıyla, işletme içerisinde ve işletme çevresinde bilgi akışı büyük ölçüde hızlanmıştır. Bilgi paylaşımının altı farklı unsuru öncelikle paylaşımın amacı ve doğası ile tanımlanmaktadır. İlk olarak organizasyonun içinden gelen bilgiler ele alınacak (Açıklama, Güncelleme), ardından organizasyonun dışından bilginin geri geldiği durumlar (Konuşma, Açık Mikrofon, Kitle Kaynak Kullanımı) üzerinde durulacaktır.

Açıklamanın amacı; hedef alıcıların (çalışanlar, ortaklar, distribütörler ve diğerleri) herkesin aynı fikirde çalışması için fikri sahiplenmesini sağlamak amacıyla insanları bir karar, yön veya strateji hakkında bilgilendirmektir. Güncelleme (Bilgi ve Eylemleri Yakalama), Normal iş akışında, insanlar yaptıklarıyla ilgili birbirlerine güncel bilgiler sunmaktadır. Bloglar, işbirliği platformları ve hatta Watshapp, Twitter gibi yayınlama araçları, kişinin ihtiyaç duyduğu anda kolayca erişilebilen güncellemeler sağlamaktadır. $\mathrm{Bu}$ güncellemelerin arşivlenebilme, aranabilme ve keşfedilebilme gibi ek faydaları bulunmaktadır. Konuşma (Operasyonları Geliştirme): işletmeler, açık bir şekilde konuşarak, faaliyetleri ve verimliliği iyileştirmek amaciyla bu konuşmalara katılmaktadır. Müşteriler, işletmenin kendi ürünleri, hizmetleri ve deneyimleri hakkında ne düşündüğünü ve işletmenin nasıl gelişebileceğini bilmek isterler. Günümüzde internet sayesinde müşteriler işletmeye çeşitli araçlarla geri bildirimde bulunabilmekte ve işletme de bu geri bildirimlere yanıt verebilmektedir. Açık Mikrofon (Katılımı Teşvik Etme): Bu uygulama da herkesin ön koşul olmaksızın katılabileceği, bir sonraki paylaşılan bilgi türünün özünü çok uygun bir şekilde yakalamaktadır. Kitle kaynak kullanımının (Bir Sorunu Birlikte Çözme) amacı, yeni fikirlerin kaynaklarını büyütmek ve yeni bir ürün veya hizmet üretmek veya geliştirmek için yeni düşünceler toplamaktır. Platformların (Standartları Belirleme ve Veri Paylaşma) amacı, kurumların ve insanların birbirleriyle nasıl etkileşim kurabileceklerini yöneten standartlar, protokoller ve kurallar oluşturmaktır. Teknoloji dünyasında, bu tür açık platformlar genellikle bir işletmenin diğerine karşı ne kadar açık olduğu konusunda uzun tartışmaları sürükleyerek "açıklık" etrafındaki tartışmalara hâkim olmaktadır (Li, 2010: 21-35).

Bilgi paylaşımında olduğu gibi, açık karar verme sadece işletmeler arasında değil, aynı zamanda işletme içerisinde de önemli ölçüde farklılık göstermektedir. İşletmelerde dört ana karar verme türü bulunmaktadır. Bunlar: merkezileştirilmiş, demokratik, fikir birliği ve dağıtılmış karar vermedir. Her zaman en iyi karar verme türü söz konusu değildir. Bunlar, kontrol derecesi, paylaşılan bilginin kapsamı ve her duruma uygun şekilde dâhil olan kişilerin seçimi açısından farklıdır.

Merkezi karar vermede, az sayıda insan merkezi kararlar almak için bilgi ve yargıya sahiptir. Merkezileştirilmiş karar vermenin avantaj1, kararlı ve hılı olabilmesi ve ayrıca, işletmenin liderine güvenildiğinde etkili olabilmesidir. Bununla birlikte bu karar verme, sürekli "komuta ve kontrol" damgası taşımaktadır. Bu nedenle çalışanlar kendilerine dikte edildiğini hissetmekte, uymak ve itaat etmek dışında çok az şansları bulunmaktadır. Demokratik karar vermede, bir gruba sınırlı sayıda seçenek sunulmakta ve karar vermek için oylama yapılmaktadır. Seçeneklerin oluşturulması ve seçilmesi basit bir "evet" veya "hayır" oyu olabilmektedir. Çalışanlar bu karar sürecinde çok daha fazla sahiplenme duygusu hissetmektedir. Uzlaşma (Kendi Kendini Yönetme) modelinde, karara dahil olan ve karardan etkilenen herkes, verilen kararda hemfikir olmak zorundadır. Bu karar verme yöntemi sıklıkla işe alımlarda kullanılmaktadır. Fakat aynı zamanda hantal bir modeldir, çünkü herkesin bir uzlaşmaya varması için fazlaca bir zaman ve çaba gerektirmektedir. Dă̆ıtılmış karar vermede ise kararları merkezden, karar vermek için bilgi ve bilginin gerçekte bulunduğu yere, tipik olarak müşteriye daha yakın bir yere itmesi bakımından öncekilerin hepsinin bir karışımıdır. Dağıtılmış modellerde karar vermek kafa karıştırıcı ve kaotik görünebilir, ancak durum tam tersidir. Herkesin aynı yönde çalışmasını sağlamak için muazzam miktarda disiplin ve planlama gereklidir. Çoğu işletme, tüm organizasyon şemasını çöpe atma lüksüne veya bunu yapma yeteneğine sahip değildir. Ancak dağıtılmış karar verme metodu ile kendi kendini yöneten ekiplerin faydaları gerçekleştirilebilir (Li, 2010: 37-43).

\subsection{Kamu Hizmeti Motivasyonu}

İş motivasyonunu etkileyen faktörler ile ilgili kuramlar genellikle insan davranışlarına etki eden faktörlere ilişkin iki hipoteze dayanmaktadır. Birinci yaklaşım kamu seçimi kuramına dayanmaktadır. Bu kuram, insanları sadece kendisini düşünen veya fedakâr olarak kabul etmektedir. Bu kurama göre; kamu çalışanları kendi çıkarlarını en üst düzeye taşıma gayretinde olan bireylerdir. Çoğu ülkenin kamu kurumlarının benimsediği performansa göre ücret buna örnek olarak verilebilir (Forest, 2008; Perry vd., 2009 Akt. Coşkun, 2015: 62). Bu yaklaşımda kamu çalışanlarının dışsal ihtiyaçları karşılandığında motive olacakları düşüncesi kabul görmektedir (Anderfuhren-Biget vd., 2010: 214). Diğer yaklaşım Kamu Hizmetleri Motivasyonu kuramı çerçevesinde ele alınmaktadır (Perry ve Wise, 1990; Perry ve Hondeghem, 2008). Bu kuram genel olarak motivasyonu "ihtiyaçlar kuramı" kapsamında değerlendirmektedir. Bu yaklaşıma göre kamu çalışanları yüksek düzeyli motiflerle hareket etmektedir. Bu anlamda iş motivasyonu kuramına değerler ve şahsiyet geri getirilmektedir. Kuram kamu politikası oluşturmanın çekiciliği gibi rasyonel bir boyuta sahip olmasının yanında kamu çalışanlarını sürekli kendi çıkarını öncelemeyen, vatanını seven, sosyal açıdan motive olmuş bireyler olarak görmektedir. $\mathrm{Bu}$ yaklaşım, son yıllarda literatüre hâkim olan ve kişisel çıkar maksimizasyonunu insan davranışının temelinde gören akılcı seçim modeline karşı bir denge oluşturmaktadır (Perry, 2000: 472). Diğer bir deyişle bu kuram, kamu kurumlarında iş motivasyonu tanımını 
genişleterek, kamuda çalışanların özel sektörde çalışan meslektaşları ile aynı davranmadıklarını, sadece dışsal motiflerden etkilenmediklerini açıklamaya çalışmaktadır (Barrows ve Wesson, 2000; Bright, 2009 Akt. Coşkun, 2015: 62).

Perry ve Wise (1990) ile Perry (1996), Knoke ve WrightIsak (1982) sınıflandırmasını esas alarak kamuda çalışanların davranışlarında normatif, norm temelli ve duygusal motiflerden oluşan üç motifin etkili olduğunu belirtmektedir. Bu bağlamda, kamu hizmetleri motivasyonu rasyonel, norm temelli ve duygusal olmak üzere üç grup etkene dayanmaktadır. Rasyonel motifler, çalışanın kendi faydasının en yüksek düzeyde olmasını temin eden eylemlerden oluşmaktadır. Norm temelli motifler, yerleşmiş ilkelere uyum sağlamak için gerçekleştirilen faaliyetlerden oluşmaktadır. Duygusal motifler ise, bireyin günlük sosyal hayatında karşılaşabileceği farklı durumlara duygusal tepkilerden oluşan davranışları etkileyen davranışlardır (Coşkun, 2015: 64).

Frederickson ve Hart (1985)'e göre; memurlar için burada temel saik, şefkat olarak adlandırılan "iyiliğin vatanseverliği" dir. İyiliksever vatanseverlik, "siyasi sınırlar içindeki tüm insanlara büyük bir sevgi ve kendilerine tanınan tüm temel haklarla korunmaları zorunluluğu" olarak tanımlanmaktadır. Araştırmacılar, bu kavramın rejim değerlerine ve başkalarına olan sevgiyi birleştirdiğini öne sürmektedir. İyiliksever vatanseverliğin belirli bir ahlaki pozisyonu temsil ettiğini iddia etseler de, duygusal bir durumu tarif ettiği de anlaşılabilir. Aslında, araştırmacıların öngördüğü ahlaki kahramanlık türüne ancak insanlığa karşı duygusal bir tepki ile ulaşılabilir (Perry, 1996: 7).

\section{Yöntem}

\subsection{Araştırma Amacı ve Hipotezleri}

$\mathrm{Bu}$ araştırmanın temel amacı sağlık çalışanlarının açık liderlik algılarının kamu hizmeti motivasyonu üzerindeki etkisini belirlemektir. Ayrıca, sağlık kurumlarına bu doğrultuda gerekli farkındalık oluşturarak yapılacak öneriler neticesinde açık liderlik ilkeleri çerçevesinde bir çalışma ortamı sunulması için gerekli düzenlemelerin yapılması amaçlanmıştır. Araştırmanın hipotezleri;

H1: Sağlık çalışanlarının açık liderliğe ilişkin algıları kamu hizmeti motivasyon düzeylerini etkilemektedir.

H2: Mesleki-Demografik bilgilere göre, açık liderlik algıları farklılık göstermektedir.

H3: Mesleki-Demografik bilgilere göre, kamu hizmeti motivasyon düzeyleri farklılık göstermektedir.

\subsection{Evren ve Örneklem}

Araştırma evreni Türkiye'nin bir ilindeki kamuya bağlı bir hastanede görev yapan sağlık çalışanlarından oluşmaktadır. Araştırmanın yapıldı ̆̆ sayısı 746'dır. Araştırma kapsamında basit tesadüfi örneklem yöntemi ile \%5 örneklem hatası doğrultusunda 350 kişiye ulaşılabilmiştir. Hesaplama, Yazıcıoğlu ve Erdoğan'ın (2014) geliştirdiği örneklem hesaplama yöntemi ile yapılmıştır. Bu yönteme göre: $\mathrm{p}=0,3 \mathrm{q}=0,7$ olasılığında $\alpha=0,05$ güven aralığ $\breve{1}_{1}$ ve 0,05 örneklem hatasıyla 750 kişi sayısındaki bir evrenin örneklem sayısı minimum 226 kişiden oluşmalıdır. Kişilerin uygulanan ankete katılmak istememeleri, izinli olma ya da nöbet sisteminde çalışma nedeniyle dağıtılan anket formlarından 242'si geri dönmüştür. $\mathrm{Bu}$ anketlerden 13 tanesi eksik ve yanlış doldurulduğundan değerlendirme dışında bırakılmış ve geriye kalan anketlerin 229'u analize uygun görülmüştür. Örneklem büyüklüğü \% 95 güven aralığında belirlenmiştir (Yazıcıŏ̆lu ve Erdoğan 2014: 85).

Anketler, araştırmanın yapılacağı kurumdan resmi yazılı izin alındıktan sonra elden dağıtılıp toplanmıştır. Eksiksiz doldurulan veriler istatistiksel değerlendirmeye alınmış ve veriler değerlendirilirken, frekans dağılımı, yüzdelik, t-testi, Anova ve pearson korelasyon testlerinden yararlanılmıştır.

\subsection{Veri Toplama Araçları}

Verileri toplamada kişisel bilgi formu, açık liderlik ölçeği ve kamu hizmeti motivasyon ölçeğinden faydalanılmıştır. Kişisel bilgiler formu, katılımcılara ait mesleki-demografik bilgileri içeren yaş, cinsiyet, medeni durum, eğitim durumu, meslekteki ve kurumdaki hizmet süresi, unvan durumu ve yöneticilik görevi olup olmama durumuna ilişkin 8 sorudan oluşmaktadır.

Açık Liderlik Ölçeği: Katılımcıların açık liderlik algılarını ölçmek için Polat ve Arabacının (2016) geliştirdiği Açık Liderlik Ölçeğinden yararlanılmıştır. Ölçek üç bölümden ve toplamda 23 ifadeden oluşmaktadır. Bu çalışma için ölçeğin cronbach alfa değeri 0,895 olarak tespit edilmiştir. Bu sonuçlara göre ölçek yüksek derecede güvenilirdir.

Kamu Hizmeti Motivasyonu Ölçeği: Katılımcıların kamu hizmeti motivasyonu düzeylerini ölçmek için Aydın ve arkadaşları (2017) tarafından geliştirilen Kamu Hizmeti Motivasyonu Ölçeğinden yararlanılmıştır. Ölçek üç bölümden ve toplamda 19 ifadeden oluşmaktadır. Bu çalışmada ölçeğin cronbach alfa değeri 0,653 ' olarak tespit edilmiştir. $\mathrm{Bu}$ sonuçlara göre ölçek oldukça güvenilirdir. İlgili anketlerde bulunan ifadelerde 5'li Likert tipi ölçek kullanılmıştır.

\subsection{Verilerin Analizi}

Anket verileri SPSS veri tabanına aktarılarak "SPSS 21.0" programı ile istatistiki analizler yapılarak değerlendirmeye tabi tutulmuş, elde edilen bilgiler değerlendirilerek yorumlanmıştır.

Açık Liderlik ve kamu hizmeti motivasyonuna ilişkin basıklık ile çarpıklık değerleri -1 ile +1 aralığında olup normal dağılım sergilemiştir (Büyüköztürk, 2018). Yine her iki değerin standart hatalarına bölünmesi sonucu -1,96 ve $+1,96$ aralığında değerler elde edilmiştir. $\mathrm{Bu}$ da normal dağılım sergilediğine işarettir. Dolayısıyla verilerin analizinde parametrik testlerden istifade edilmiştir. İki alt grubu olan veriler için $\mathrm{T}$ Testi, ikiden fazla alt gruptan oluşan veriler için de Anova Testi kullanılmış olup değişkenler arasındaki etki düzeyini ölçmek için regresyon analizinden yararlanılmıştır.

\subsection{Araştırma Etiği}

Araştırmanın yürütülebilmesi için İl Sağlık Müdürlüğünden gereken yazılı izin alınmıştır. Konu ile ilgili 28.02.2019 tarihi ile Muş Alparslan Üniversitesi Bilimsel Araştırma ve Yayın Etiği Kurulu'ndan etik kurul kararı alınmıştır (No: 11). Çalışmaya katılan katılımcılara çalışmanın amacı 
açıklanmış, gönüllü ve istekli olmalarına özen gösterilmiştir.

\section{Bulgular}

$\mathrm{Bu}$ bölümde kamu hizmeti motivasyonu ile açık liderlik ve alt boyutları arasındaki ilişki korelasyon analiziyle test edilmiştir. Açık liderlik alt boyutları bağımsız değişken, kamu hizmeti motivasyonu da bağımlı değişken şeklinde kabul edilmiş, bağımsız değişkenlerin bağımlı değişkene olan etkisi çoklu doğrusal regresyon analiziyle değerlendirilmeye tabi tutulmuştur. Tablo 2'de Katılımcıların mesleki-demografik bilgilerine ilişkin bilgiler verilmişstir.

Tablo 2. Katılımcıların Mesleki-Demografik Özellikleri

\begin{tabular}{|c|c|c|c|}
\hline & & Sayı & Yüzde \\
\hline \multirow{4}{*}{ Yaş } & $18-25$ & 35 & 15,3 \\
\hline & $26-35$ & 122 & 53,3 \\
\hline & $36-45$ & 50 & 21,8 \\
\hline & 46 ve Üstü & 22 & 9,6 \\
\hline \multirow{2}{*}{ Cinsiyet } & Kadın & 89 & 38,9 \\
\hline & Erkek & 140 & 61,1 \\
\hline \multirow{2}{*}{ Medeni Durum } & Evli & 153 & 66,8 \\
\hline & Bekâr & 76 & 33,2 \\
\hline \multirow{4}{*}{$\begin{array}{l}\text { Öğrenim } \\
\text { Durumu }\end{array}$} & Lise & 72 & 31,4 \\
\hline & Ön lisans & 73 & 31,9 \\
\hline & Lisans & 30 & 13,1 \\
\hline & Lisansüstü & 54 & 23,6 \\
\hline \multirow{4}{*}{$\begin{array}{l}\text { Meslekte } \\
\text { Çalışma Süresi }\end{array}$} & $0-3$ y1l & 30 & 13,1 \\
\hline & 4-6 y1l & 62 & 27,1 \\
\hline & $7-9$ y1l & 72 & 31,4 \\
\hline & 10 yıl ve üstü & 65 & 28,4 \\
\hline \multirow{4}{*}{$\begin{array}{l}\text { Kurumda } \\
\text { Çalışma Süresi }\end{array}$} & $0-3$ y1l & 75 & 32,8 \\
\hline & $4-6$ yil & 54 & 23,6 \\
\hline & $7-9$ yil & 81 & 35,4 \\
\hline & 10 yıl ve üstü & 19 & 8,3 \\
\hline \multirow{3}{*}{ Unvan Durumu } & Tabip & 23 & 10,1 \\
\hline & $\begin{array}{l}\text { Tabip dışı sağlık } \\
\text { personeli }\end{array}$ & 82 & 35,8 \\
\hline & İdari personel & 124 & 54,1 \\
\hline \multirow{3}{*}{$\begin{array}{l}\text { Yöneticilik } \\
\text { Görevi Olma } \\
\text { Durumı } \\
\text { TOPLAM }\end{array}$} & Evet & 38 & 16,6 \\
\hline & Hayır & 191 & 83,4 \\
\hline & & 229 & 100 \\
\hline
\end{tabular}

Tablo 2. demografik bilgiler açısından incelendiğinde katılımcıların yarısından fazlası \%53,3 26-35 yaş sağlık çalışanlarından oluşmaktadır. Cinsiyet açısından bakıldığında katılımcıların çoğunluğu $(\% 61,1)$ erkeklerden oluşurken, daha düşük düzeyde katılım $(\% 38,9)$ ise kadınlardan oluşmaktadır. Öğrenim durumu açısından, en yüksek katılımı $(\% 31,9)$ ön lisans mezunları oluştururken, bunu \%31,4 ile ise mezunu katılımcilar, \%23,6 ile lisansüstü mezunları ve \%13,1 ile de lisans mezunları izlemektedir. Meslekte çalışma süresine bakıldığında, en fazla katılımı \%31,4 ile 7-9 yıl çalışanlar oluşturmakta, bunu \%28,4 ile 10 yıl ve üstü çalışanlar ve \%27,1 ile 4-6 yıl çalışanlar izlemektedir. En az katılım ise \% 13,1 ile 0-3 yıl süre ile çalışanlardan oluşmaktadır. Kurumda çalışma süresine bakıldığında, en yüksek katılımı \%35,4 ile 7-9 yıl çalışanlar oluşturmakta, bunu \%32,8 ile 0-3 y1l çalışanlar izlemektedir. En az katılım ise \% 8,3 ile 10 yıl ve üstü süre ile çalışanlardan oluşmaktadır. Katılımcıların çalıştıkları unvanlara bakıldığında, yarısından fazlası \%54,1 idari personeller olarak görülmekteyken, bunu $\% 35,8$ ile tabip dışı sağlık personeli, \%10,1 ile tabipler izlemektedir. Yöneticilik görevi olma durumuna göre bakıldığında katılımcıların büyük çoğunluğunun $(\% 83,4)$ yöneticilik görevi olmadığı, düşük düzeyde katılım $(\% 16,6)$ ise yöneticilik görevi olanlardan oluşmaktadır.

\subsection{Geçerlik ve Güvenirliğe İlişkin Bulgular}

Anketin geçerliliği için yapılan doğrulayıcı faktör analizine açık liderlik ölçeği için üç faktör ve 23 maddeyle başlanmış, öncelikle maddelerin $\mathrm{t}$ değerleri incelenmiş ve 5 maddenin $\mathrm{t}$ değerlerinin anlamlı olmadığı tespit edilmiştir. Ayrıca bu maddelerin "Standardized Solution" değerlerine bakıldığında faktör yük değerlerinin 0.30'dan düşük olduğu görülmüştür. $\mathrm{Bu}$ maddeler anketten çıkarılarak 18 madde üzerinden analize devam edilmiştir. Kamu hizmeti motivasyonu ölçeği için yapılan doğrulayıcı faktör analizinde de maddelere ilişkin $\mathrm{t}$ değerleri incelenmiş ve 8 maddenin $\mathrm{t}$ değerlerinin anlamlı olmadığı tespit edilmiştir. Ayrıca bu maddelere ilişkin faktör yük değerlerinin 0.30'dan düşük olduğu görülmüştür. Bu maddeler anketten çıkarılarak 11 madde üzerinden analize devam edilmiştir. Anket güvenirliği, iç tutarlılık katsayıları değerlendirilerek her ölçek ve alt boyutlar için ayrıca hesaplanmıştır. Tablo 3'te ölçeklerin ve alt boyutlarının güvenirlik sonuçlarına ilişkin bilgiler verilmiştir.

Tablo 3. Ölçeklerin ve Alt Boyutlarının Güvenirlik Sonuçları

\begin{tabular}{lcc}
\hline Ölçek & $\mathrm{n}$ & Cronbach \\
\hline Açık Liderlik & $\mathbf{1 8}$ & $\mathbf{0 , 8 9 5}$ \\
\hline Gücün kabulü ve sürekli paylaşım & 8 & 0,921 \\
\hline Merakı destekleme ve hesap verebilirlik & 6 & 0,854 \\
\hline Sosyal ağların etkin kullanımı & 4 & 0,735 \\
\hline Kamu Hizmeti Motivasyonu & $\mathbf{1 1}$ & $\mathbf{0 , 6 5 3}$ \\
\hline Kamu yararına bağlılık & 4 & 0,780 \\
\hline Kamusal duyarlılık & 4 & 0,670 \\
\hline Topluma karş1 sorumluluk & 3 & 0,497 \\
\hline
\end{tabular}

Alpar (2020: 581)'a göre anketin güvenilirliğinin test edilmesinde kullanılan Cronbach Alfa güvenilirlik katsayısı 60-79 aralığında olduğunda oldukça güvenilir, 80-100 aralığında olduğunda ise ölçek yüksek güvenilirlikte kabul edilmektedir. Açık liderlik ölçeğinin geçerliliği alt boyutlarda incelendiğinde gücün kabulü ve sürekli paylaşım alt boyutunda güvenirlik katsayısının en büyük $(=0,921)$, sosyal ağların etkin kullanımı alt boyutunda ise güvenirliğin en düşük $(=0,735)$ olduğu tespit edilmiştir. Açık liderlik ölçeği tüm alt boyutları ile birlikte değerlendirildiğinde anketin güvenilirliğinin $(=0,895)$ olması yüksek derecede güvenilir olduğunu göstermiştir. Kamu hizmeti motivasyonu ölçeğinin güvenirlik katsayısının ise $(=0,653)$ olarak tespit edilmesi, anketin oldukça güvenilir olduğunu göstermiştir.

4.2. Değişkenler Arasındaki Korelasyonlar ve Regresyon Analizi Sonuçları 
$\mathrm{Bu}$ bölümde öncelikle kamu hizmeti motivasyonu, açık liderlik ve alt boyutları arasındaki ilişki pearson korelasyon analiziyle test edilerek bu değişkenlerin ortalama ve standart sapmaları hesaplanmıştır. Daha sonra açık liderlik alt boyutları bağımsız değişkenler, kamu hizmeti motivasyonu da bağımlı değişken şeklinde kabul edilerek bağımlı değişken üzerinde bağımsız değişkenlerin etkisi çoklu doğrusal regresyon analiziyle incelenmiştir.

Tablo 4'te kamu hizmeti motivasyonu ile açık liderlik ve alt boyutlarının ortalama, standart sapma ve korelasyon katsayıları verilmiştir.

Tablo 4. Değişkenler Arasındaki Pearson Korelasyon Analizi

\begin{tabular}{|c|c|c|c|c|c|c|c|c|}
\hline & Ort & S.S & & 1 & 2 & 3 & 4 & 5 \\
\hline \multirow{2}{*}{ 1. Açık Liderlik } & \multirow{2}{*}{3,80} & \multirow{2}{*}{0,51} & $\mathrm{R}$ & 1 & 0,890 & 0,661 & 0,658 & 0,337 \\
\hline & & & $\mathrm{P}$ & & 0,000 & 0,000 & 0,000 & 0,000 \\
\hline \multirow[t]{2}{*}{ 2. Gücün kabulü ve sürekli paylaşım } & \multirow[t]{2}{*}{3,75} & \multirow{2}{*}{0,75} & $\mathrm{R}$ & & 1 & 0,296 & 0,541 & 0,190 \\
\hline & & & $\mathrm{P}$ & & & 0,000 & 0,000 & 0,175 \\
\hline \multirow{2}{*}{$\begin{array}{l}\text { 3. Merak1 destekleme ve hesap } \\
\text { verebilirlik }\end{array}$} & \multirow{2}{*}{3,80} & \multirow{2}{*}{0,66} & $\mathrm{R}$ & & & 1 & 0,205 & 0,587 \\
\hline & & & $\mathrm{P}$ & & & & 0,002 & 0,000 \\
\hline \multirow[t]{2}{*}{ 4. Sosyal ağların etkin kullanımı } & \multirow[t]{2}{*}{3,90} & \multirow[t]{2}{*}{0,52} & $\mathrm{R}$ & & & & 1 & 0,332 \\
\hline & & & $\mathrm{P}$ & & & & & 0,025 \\
\hline \multirow[t]{2}{*}{ 5. Kamu Hizmeti Motivasyonu } & \multirow[t]{2}{*}{4,13} & \multirow[t]{2}{*}{0,35} & $\mathrm{R}$ & & & & & 1 \\
\hline & & & $\mathrm{P}$ & & & & & \\
\hline
\end{tabular}

\section{$\mathrm{P}<0,05$}

Tablo 4. incelendiğinde açık liderlik puanı ortalamasının 3,80 $\pm 0,51$ olduğu, kamu hizmeti motivasyonu ortalamasının da $4,13 \pm 0,35$ olduğu görülmektedir. Açık liderlik alt boyutları incelendiğinde ise en yüksek puan sahibi boyutun sosyal ağların etkin kullanımı boyutu $(3,90 \pm 0,52)$, en düşük puan sahibi boyutun ise gücün kabulü ve sürekli paylaşım boyutu $(3,75 \pm 0,75)$ olduğu görülmektedir. Ancak ortalamalara bakıldığında açık liderlik boyutlarının ortalamalarının birbirine yakın değerlerden oluştuğu söylenebilir. Korelasyon katsayıları incelendiğinde ise, açık liderlik ile kamu hizmeti motivasyonu arasında pozitif yönlü orta kuvvette bir ilişki görülmektedir. Açık liderlik gücün kabulü ve sürekli paylaşım boyutu dışındaki tüm alt boyutları ile kamu hizmeti motivasyonu arasında pozitif yönlü orta kuvvette bir ilişki bulunmaktadır. Açık liderlik ve tüm alt boyutları arasında pozitif yönlü bir ilişki söz konusudur. En yüksek ilişki gücün kabulü ve sürekli paylaşım alt boyutunda görülürken en düşük ilişki ise sosyal ağların etkin kullanımı alt boyutunda görülmektedir $(\mathrm{p}<0,05)$.

Tablo 5. Çoklu Doğrusal Regresyon Analizi Sonuçları

\begin{tabular}{lccccccc}
\hline Değişken & B & Std. Hata & $\boldsymbol{\beta}$ & $\mathbf{t}$ & $\mathbf{p}$ & $\begin{array}{c}\text { VIF } \\
\text { Durbin- } \\
\text { Watson }\end{array}$ \\
\hline Sabit & 2,917 & 0,164 & - & 17,755 & 0,000 & - & \\
Gücün Kabulü ve Sürekli Paylaşım & 0,163 & 0,031 & 0,134 & 2,059 & 0,041 & 2,939 & 1,695 \\
Merakı Destekleme ve Hesap Verebilirlik & 0,327 & 0,030 & 0,611 & 10,891 & 0,000 & 3,240 & 2,593 \\
Sosyal Ağların Etkin Kullanımı & 0,054 & 0,043 & 0,080 & 1,260 & 0,209 &
\end{tabular}

$\mathrm{F}=41,640 \quad \mathrm{R} 2=0,357 \quad \mathrm{R}=0,597 \quad \mathrm{p}<0,001 \quad * \mathrm{p}<0,05$

Tablo 5'e göre; açık liderlik algısı, kamu hizmeti motivasyonunu pozitif olarak anlamlı arttırmaktadır. Açık liderliğin iki alt boyutu (gücün kabulü ve sürekli paylaşım ile merakı destekleme ve hesap verebilirlik) kamu hizmeti motivasyonunu anlamlı olarak arttırmaktadır.
Korelasyon katsayısı 1 olduğunda, mükemmel pozitif ilişki; -1 olduğunda mükemmel negatif bir ilişki; 0 olduğunda ise ilişki olmadığını göstermektedir. Korelasyon katsayısı yorumlanırken üzerinde tam olarak uzlaşı sağlanmış aralıklar olmamakla birlikte, korelasyonun yorumlanmasında şu sinırlar kullanılabilir. Korelasyon katsayısı mutlak değer olarak, 0,70-1,00 aralığında olduğunda, yüksek; 0,70-0,30 aralığında olduğunda, orta; 0,30-0,00 aralığında olduğunda ise, düşük düzeyde bir ilişki şeklinde tanımlanmaktadır (Büyüköztürk, 2018). Buna göre kamu hizmeti motivasyonu ile açık liderlik ve iki alt boyutu arasında pozitif yönlü ve orta düzeyde bir ilişki olduğu ve çalışanların açık liderlik algısında artış oldukça kamu hizmeti motivasyonunun da artacağı söylenebilir.

Tablo 5'te açık liderlik alt boyutu değişkenlerinin kamu hizmeti motivasyonu üzerindeki etkisini belirlemek amacıyla yapılan çoklu regresyon analizi sonuçları verilmiştir. 
$\mathrm{Bu}$ çalışmada $\mathrm{VIF}>10$, kritik değeri çoklu bağıntının emaresi olarak kabul edilmiştir. Durbin- Watson katsayısının 1,5 ile 2,5 aralığında olması ve VIF katsayılarının 10'dan düşük olması otokorelasyon ve çoklu bağlantı problemleri olmadığını göstermektedir (Büyüköztürk, 2018: 99). Bu çalıșmada Durbin- Watson katsayısı 1,695'tir ve VIF değerleri 2,593 ile 3,240 arasında değişmektedir. Buna göre otokorelasyon ve çoklu bağlantı problemleri bulunmamaktadir. Ayrica kurulan regresyon modelinin doğrusal olduğu ve modelin istatiksel olarak anlamlı olduğu tespit edilmiştir $(\mathrm{F}=41,640 ; \mathrm{p}<0,001)$. Bununla birlikte $\mathrm{R} 2=0,357$ olarak hesaplanmış, açık liderliğin kamu hizmeti motivasyonunu açıklama yüzdesi $\% 35,7$ olarak tespit edilmiştir. Standardize edilmiş regresyon katsayısına $(\beta)$ göre, yordayıcı değişkenlerin kamu hizmeti motivasyonu üzerindeki görece önem sırası; merakı destekleme ve hesap verebilirlik, gücün kabulü ve sürekli paylaşım ve sosyal ağların etkin kullanımıdır. Regresyon katsayılarının anlamlılığı ile ilgili sonuçlar incelendiğinde ise, merakı destekleme ve hesap verebilirlik ile gücün kabulü ve sürekli paylaşım değişkenlerinin kamu hizmeti motivasyonu üzerinde önemi olan anlamlı bir yordayıc1 olduğu görülmektedir. Sosyal ağların etkin kullanımı değişkeninin ise önemli bir etkisinin olmadığı görülmektedir.

Araştırmada ayrıca katılımcıların yaş, cinsiyet, medeni durum, eğitim durumu, meslekte ve kurumda çalışma süresi, unvan durumu ile yöneticilik görevi olma durumuna göre açık liderlik algısı ve kamu hizmeti motivasyonu düzeylerinde bir farklılık olup olmadığı da incelenmiştir.

Tablo 6. Cinsiyet, Medeni Durum ve Yöneticilik Görevi Olma Durumu İçin Yapılan T Testi

\begin{tabular}{|c|c|c|c|c|c|c|c|c|}
\hline & & & \multicolumn{3}{|c|}{ Açık Liderlik } & \multicolumn{3}{|c|}{ Kamu Hizmeti Motivasyonu } \\
\hline & & $\mathrm{N}$ & Ort $\pm S S$ & $\mathrm{~F}$ & $\mathrm{P}$ & Ort $\pm S S$ & $\mathrm{~F}$ & $\mathrm{P}$ \\
\hline \multirow{2}{*}{ Cinsiyet } & Kadın & 89 & $3,77 \pm 0,57$ & \multirow[b]{2}{*}{4,080} & \multirow[b]{2}{*}{,045 } & $4,10 \pm 0,34$ & \multirow[b]{2}{*}{1,009} & \multirow[b]{2}{*}{, 316} \\
\hline & Erkek & 140 & $3,83 \pm 0,48$ & & & $4,15 \pm 0,36$ & & \\
\hline \multirow{2}{*}{ Medeni Durum } & Evli & 153 & $3,78 \pm 0,50$ & \multirow[b]{2}{*}{,398 } & \multirow[b]{2}{*}{, 529} & $4,11 \pm 0,36$ & \multirow[b]{2}{*}{,431 } & \multirow[b]{2}{*}{, 512} \\
\hline & Bekâr & 76 & $3,84 \pm 0,55$ & & & $4,19 \pm 0,33$ & & \\
\hline \multirow{2}{*}{$\begin{array}{l}\text { Yöneticilik } \\
\text { Görevi Olma } \\
\text { Durumu }\end{array}$} & Evet & 38 & $3,89 \pm 0,88$ & \multirow[b]{2}{*}{, 157} & \multirow[b]{2}{*}{693} & $4,12 \pm 0,20$ & \multirow[b]{2}{*}{, 085} & \multirow[b]{2}{*}{, 771} \\
\hline & Hayır & 191 & $3,78 \pm 0,73$ & & & $4,14 \pm 0,24$ & & \\
\hline
\end{tabular}

$* \mathrm{p}<0.05$

Katılımcıların açık liderlik algılarının mesleki-demografik özelliklere göre karşılaştırıldığ $\mathrm{T}$ testine göre; açık liderlik algısının cinsiyet grupları arasında anlamlı bir farkın bulunduğu; medeni durum ve yöneticilik görev durumu grupları arasında ise anlamlı bir farkın bulunmadı $\breve{g}_{1}$ sonucuna ulaşılmıştır. Erkek katılımcıların kadın katılımcılardan daha yüksek ortalamaya sahip oldukları görülmüştür. Katılımcıların kamu hizmeti motivasyonu düzeylerinin mesleki-demografik özelliklere göre karşılaştırıldığı T testine göre; kamu hizmeti motivasyonu düzeylerinin cinsiyet, medeni durum ve yöneticilik görev durumu grupları arasında anlamlı bir farkın bulunmadığı sonucuna ulaşılmıştır.

Tablo 7. Yaş, Unvan, Öğrenim Durumu, Meslekte ve Kurumda Çalışma Süresi Durumu İçin Yapılan Anova Testi

\begin{tabular}{|c|c|c|c|c|c|c|c|c|}
\hline & & \multicolumn{3}{|c|}{ Açık Liderlik } & \multicolumn{4}{|c|}{ Kamu Hizmeti Motivasyonu } \\
\hline & & $\mathbf{N}$ & Ort \pm SS & $\mathbf{F}$ & $\mathbf{P}$ & Ort \pm SS & $\mathbf{F}$ & $\mathbf{P}$ \\
\hline \multirow{4}{*}{ Yaş } & $18-25$ & 35 & $3,81 \pm 0,45$ & \multirow{4}{*}{, 745} & \multirow{4}{*}{, 526} & $4,14 \pm 0,20$ & \multirow{4}{*}{,456 } & \multirow{4}{*}{,714 } \\
\hline & $26-35$ & 122 & $3,71 \pm 0,49$ & & & $4,11 \pm 0,24$ & & \\
\hline & $36-45$ & 50 & $3,73 \pm 0,47$ & & & $4,15 \pm 0,21$ & & \\
\hline & 46 ve Üstü & 22 & $3,83 \pm 0,38$ & & & $4,12 \pm 0,19$ & & \\
\hline \multirow{3}{*}{ Unvan } & Tabip & 23 & $3,76 \pm 0,54$ & \multirow{3}{*}{4,233} & \multirow{3}{*}{,016 } & $4,21 \pm 0,24$ & \multirow{3}{*}{5,377} & \multirow{3}{*}{,005 } \\
\hline & $\begin{array}{l}\text { Tabip Dışı } \\
\text { Sağlık Personeli }\end{array}$ & 82 & $3,62 \pm 0,56$ & & & $4,26 \pm 0,24$ & & \\
\hline & İdari personel & 124 & $3,82 \pm 0,39$ & & & $4,15 \pm 0,20$ & & \\
\hline \multirow{4}{*}{$\begin{array}{l}\text { Öğrenim } \\
\text { Durumu }\end{array}$} & Lise & 72 & $3,69 \pm 0,42$ & \multirow{4}{*}{2,041} & \multirow{4}{*}{,009 } & $4,12 \pm 0,21$ & \multirow{4}{*}{, 722} & \multirow{4}{*}{, 540} \\
\hline & Ön lisans & 73 & $3,73 \pm 0,50$ & & & $4,10 \pm 0,24$ & & \\
\hline & Lisans & 30 & $3,75 \pm 0,56$ & & & $4,17 \pm 0,24$ & & \\
\hline & Lisansüstü & 54 & $3,79 \pm 0,43$ & & & $4,13 \pm 0,20$ & & \\
\hline \multirow{4}{*}{$\begin{array}{l}\text { Meslekte } \\
\text { Çalışma Süresi }\end{array}$} & $0-3$ yil & 30 & $3,73 \pm 0,55$ & \multirow{4}{*}{, 343} & \multirow{4}{*}{,794 } & $4,22 \pm 0,24$ & \multirow{4}{*}{2,688} & \multirow{4}{*}{, 047} \\
\hline & $4-6$ y1l & 62 & $3,79 \pm 0,45$ & & & $4,13 \pm 0,22$ & & \\
\hline & $7-9$ y1l & 72 & $3,75 \pm 0,44$ & & & $4,12 \pm 0,21$ & & \\
\hline & 10 y1l ve üstü & 65 & $3,70 \pm 0,50$ & & & $4,08 \pm 0,23$ & & \\
\hline \multirow{2}{*}{$\begin{array}{l}\text { Kurumda } \\
\text { Çalışma Süresi }\end{array}$} & $0-3$ yil & 75 & $3,71 \pm 0,54$ & \multirow{2}{*}{,652 } & \multirow{2}{*}{, 582} & $4,15 \pm 0,24$ & \multirow{2}{*}{800} & \multirow{2}{*}{,495 } \\
\hline & $4-6$ y1l & 54 & $3,70 \pm 0,47$ & & & $4,09 \pm 0,22$ & & \\
\hline
\end{tabular}




\begin{tabular}{lll}
$7-9$ y1l & 81 & $3,79 \pm 0,43$ \\
\hline 10 y1l ve üstü & 19 & $3,81 \pm 0,40$
\end{tabular}$\quad$\begin{tabular}{l}
$4,12 \pm 0,22$ \\
\cline { 2 - 2 }
\end{tabular}

*p $<0.05$

Katılımcıların açık liderlik algılarının mesleki-demografik özelliklere göre karşılaştırıldığı Anova testine göre; açık liderlik algısının unvan durumu ve öğrenim durumu grupları arasında anlamlı bir farkın bulunduğu; yaş, meslekte çalışma süresi ve kurumda çalışma süresi grupları arasında ise anlamlı bir farkın bulunmadığı sonucuna ulaşılmıştır $(p<0,05)$. Unvan durumu ve öğrenim durumu grupları arasında hangi gruptan kaynaklı farkın olduğunu test etmek amaciyla yapılan Tukey HSD testi sonuçları doğrultusunda; idari personelin açık liderlik algısı düzeyinin tabipler ve tabip dışı sağlık personeline nazaran daha yüksek olduğu söylenebilir. Ayrıca lisansüstü eğitim düzeyine sahip çalışanların açık liderlik ile ilgili algılarının diğer eğitim düzeylerinden daha yüksek olduğu sonucuna ulaşılmıştır.

Katılımcıların kamu hizmeti motivasyonu düzeylerinin mesleki-demografik özelliklere göre karşılaştırıldığı Anova testine göre; kamu hizmeti motivasyonu düzeylerinin unvan ve meslekte çalışma süresi grupları arasında anlamlı bir farkın bulunduğu; yaş, öğrenim durumu ve kurumda çalışma süresi grupları arasında ise anlamlı bir farkın bulunmadığ 1 sonucuna ulaşılmıştır $(\mathrm{p}<0,05)$. Hangi gruptan kaynaklı farkın olduğunu test etmek amacıyla yapılan Tukey HSD testi sonuçları doğrultusunda; tabip dişı sağlık personelinin kamu hizmeti motivasyon düzeyinin tabipler ve idari personeline nazaran daha yüksek olduğu söylenebilir. Ayrıca meslekte çalışma süresi 0-3 yıl arasında olan çalışanların kamu hizmeti motivasyonu düzeylerinin diğer gurupların düzeylerinden daha yüksek olduğu sonucuna ulaşılmıştır. Başka bir ifade ile meslekte çalışma süresi arttıkça kamu hizmeti motivasyonu düzeyi azalmaktadır.

$\mathrm{Bu}$ sonuçlara göre; hipotezlerin durumu $(0,05$ anlamlılık düzeyinde) aşağıdaki gibidir.

- H1: "Sağlık çalışanlarının açık liderliğe ilişkin algıları kamu hizmeti motivasyon düzeylerini etkilemektedir" hipotezi kabul edilmiştir.

- H2 "Mesleki-Demografik bilgilere göre, açık liderlik algıları farklılık göstermektedir" hipotezi kısmen kabul edilmiştir.

- H3 "Mesleki-Demografik bilgilere göre, kamu hizmeti motivasyon düzeyleri farklılık göstermektedir" hipotezi kısmen kabul edilmiştir.

\section{Sonuç}

Günümüz liderlerinin, taşımaları gerekli olan birçok özellik ile birlikte, birer açık lider vasfına sahip olmaları gerekmektedir. Zira açık liderlerin başarılı olabilmeleri için kontrol yönelimli davranışlar dışında özgüven sahibi oldukları bilinmektedir. Bunun yanında amaçlarına ulaşmak için birlikte çalıştıkları kişileri, kendilerini adama konusunda cesaretlendirme yeterliliği sahibidirler. $\mathrm{Bu}$ şekilde açık liderler çalışmalarında çalışanları ile aralarında güven temeline dayanan çeşitli ilişki ağları kurmakta ve hedeflerini gerçekleştirmede iletişim teknolojilerini etkili bir araç olarak kullanmaktadır.
Son yıllarda kamuda yapılan reformlar, kamu kurumlarında çalışanların motivasyonunu sağlamada dışsal/parasal faktörler üzerinde durmaktadır. $\mathrm{Bu}$ bağlamda, Kamu kurumlarının "maddi ödüllendirme" yi esas alan performansa dayalı ücretlendirme uygulamaları gittikçe yaygınlaşmaktadır. OECD üyesi ülkelerin üçte ikisinden fazlasında, kamuda mali ödüle dayalı performansa dayalı ücret programları uygulanmıştır (OECD, 2005). KHM kuramı, performansa dayalı ücret uygulamalarının alternatifi bir düşünce olarak geliştirilen bir kuramdır. $\mathrm{Bu}$ kuramın savunucuları 1srarla kamu kurumlarında çalışanların özel sektörde çalışanlardan farklı iş motivasyonu sahibi oldukları üzerinde durmaktadır. Bu kuram, kurumlarında çalışanların içsel tatmine dışsal unsurlardan (ücret-maddi ödül) daha fazla değer verdiğini savunmaktadır. Nitekim, Crewsen, (1997), Jurkiewicz vd. (1998) ve Lyons vd. (2006) tarafından yapılan bazı ampirik çalışma sonuçları bunu doğrular niteliktedir (Coşkun, 2015: 68-69).

Araştırmadan elde edilen bulgulara göre; açık liderlik algısının kamu hizmeti motivasyonu üzerinde pozitif yönlü anlamlı bir etkisi vardır. Ayrıca açık liderliğin kamu hizmeti motivasyonunu açıklama yüzdesi \%35,7 olarak tespit edilmiştir. Başka bir deyişle açık liderlik algısındaki artış kamu hizmeti motivasyonunu da arttırmaktadır.

Araştırma bulgularına bakıldığında, kurumdaki açık liderlik ve kamu hizmeti motivasyonu düzeylerinin yüksek düzeyde olduğu görülmüştür. Araştırma sonucunda çalışanların açık liderlik ortalamasının 3,80; kamu hizmeti motivasyonu ortalamasının ise 4,13 olduğu tespit edilmiştir. Bu bulgunun Çınar ve arkadaşları (2012) tarafindan belirlenen değerlendirme aralığına göre yüksek olduğu söylenebilir. Araştırma sonuçları daha önce yapılan araştırma sonuçlarıyla karşılaştırıldığında Piaw ve Ting (2014) ve Uçar (2015) çalışmalarında yöneticilerin büyük bir kısmının ve çoğunun açık liderlik davranışları sergilediklerini tespit etmiştir. Polat (2015) ve Caz (2018) ise çalışmalarında açık liderlik düzeyinin orta düzeyde olduğunu tespit etmiştir (Piaw ve Ting, 2014; Uçar, 2015; Polat, 2015; Caz, 2018). Araştırmalardaki örneklem gruplarının farklı olması (üniversitelerde görev yapan akademik ve idari personel-okulda görev yapan öğretmenler) bunun nedenlerinden birisi olarak değerlendirilebilir.

Ayrıca katılımcıların mesleki-demografik demografik bilgilerine göre açık liderlik algısı düzeylerinde ve kamu hizmeti motivasyonunda kısmen bir farklılık olduğu da tespit edilmiştir.

Katılımcıların açık liderlik algıları mesleki-demografik özelliklere göre incelendiğinde: cinsiyet, unvan durumu ve öğrenim durumu grupları arasında anlamlı bir farkın bulunduğu; medeni durum, yöneticilik görev durumu, yaş, meslekte çalışma süresi ve kurumda çalışma süresi grupları arasında ise anlamlı bir farkın bulunmadığı sonucuna ulaşılmıştır.

Çalışmada erkek katılımcıların kadın katılımcılardan daha yüksek ortalamaya sahip oldukları görülmüştür. Caz 
(2018), Yildız (2019) ve Gürler (2020) yaptıkları çalışmalarda cinsiyet açısından anlamlı bir farkın bulunmadığı sonucuna ulaşmıştır. Polat (2015) ise cinsiyet değişkeninin kurumdaki açık liderlik düzeyi üzerinde anlamlı bir etkisinin olduğu sonucuna ulaşmıştır. Yine idari personelin açık liderlik algısı düzeyinin tabipler ve tabip dışı sağlık personeline nazaran daha yüksek olduğu söylenebilir. Bu bulgu, Caz (2018) tarafindan yapılan araştırma sonuçlarıyla benzerlik göstermektedir. Ayrıca lisansüstü eğitim düzeyine sahip çalışanların açık liderlik ile ilgili algıları diğer eğitim düzeylerine sahip çalışanların algılarından daha yüksek bulunmuştur. Bu bulgu, Polat (2015) ve Gürler (2020)' in araştırma sonuçlarıyla benzerlik göstermektedir.

Katılımciların kamu hizmeti motivasyonu algılarına mesleki-demografik özelliklere göre bakıldığında: unvan durumu ve meslekte çalışma süresi grupları arasında anlamlı bir farkın bulunduğu; yaş, cinsiyet, medeni durum, öğrenim durumu, yöneticilik görev durumu ve kurumda çalışma süresi grupları arasında ise anlamlı bir farkın bulunmadığı sonucuna ulaşılmıştır.

Tabip dişı sağlık personelinin kamu hizmeti motivasyon düzeyinin tabipler ve idari personeline nazaran daha yüksek olduğu söylenebilir. Ayrıca meslekte çalışma süresi 0-3 yıl arasında olan çalışanların kamu hizmeti motivasyonu düzeylerinin diğer grupların düzeylerinden daha yüksek olduğu sonucuna ulaşılmıştır. Başka bir ifade ile meslekte çalışma süresi arttıkça kamu hizmeti motivasyonu düzeyi azalmaktadır. Prysmakova (2013)'nın Avrupa Birliği üyesi olan ve olmayan 26 Avrupa ülkesinde yaptı̆̆ 1 araștırma KHM ile ilgili yapılmış en kapsamlı çalışmadır. Çalışmada, kamuda çalışan görevlilerin ödül motivasyonları iç veya dış odaklı olması bakımından özel sektör çalışanlarıyla karşılaştırma yapılmıştır. Çalışmaya Türkiye, Kıbrıs ve İsrail de dahil edilmiştir. Araştırma sonuçları genel olarak incelendiğinde, kamu kurumlarında başkalarına yardımcı olmaya yöneltilen önemle kamu görevlisi olma arasında pozitif bir ilişkinin varlığı tespit edilmiștir. Öztürk ve Dündar (2003) tarafindan kamu çalışanlarında motivasyonu sağlayan faktörler konulu bir çalışma yapılmıştır. Bu çalıșmada üç bakanlığın merkez teşkilatında çalışan farklı pozisyondaki yönetici ve çalışanların görüşleri araştırılmıştır. Çalışmanın bulguları, yöneticilerin manevi ödüllere daha fazla önem verdiğini, diğer çalışanların ise maddi ödüllere daha fazla önem verdiklerini göstermiștir. Bright (2005)'ın kamu hizmeti motivasyonunun çeşitli değişkenler açısından test edildiği çalışmasında, kadınlar, yöneticiler ve eğitim düzeyi yüksek olan bireylerde kamu hizmeti motivasyonu düzeyinin daha yüksek olduğu tespit edilmiştir.

Çalışmanın ileride yapılacak diğer çalışmalara da yol göstermesi beklenmektedir. Araştırma, sadece sağl1k sektörü çalışanları üzerinde yapıldığından, diğer sektörlere de uygulanmasının konunun gelişimine katkısı olacaktır. $\mathrm{Bu}$ çalışma, Türkiye'de bir ildeki bir kamu hastanesinde çalışan sağlık çalışanlarına uygulanmıştır. Tüm sağlık çalışanlarıyla ilgili genelleme yapılabilmesi için, diğer illerdeki kamu ve özel sektörde çalışan sağllk çalışanlarına de benzer bir çalışmanın uygulanması konuya katkı sağlayacaktır.

\section{Kaynakça}

Alpar, R. (2020). Uygulamal istatistik ve geçerlilikgüvenilirlik. (6. Baskı). Ankara: Detay Yayıncılık.

Anderfuhren-Biget, S., Varone F., Giauque D., \& Ritz, A. (2010). Motivating employees of the public sector: Does public sector motivation matter?. International Public Sector Management, 13(3), 213-246.

Aydın, İ., Demirkasımoğlu, N., Güner Demir, T., \& Ş1ldıroğlu, Ö. E. (2017). Kamu hizmeti motivasyonu ölçeğinin geliştirilmesi. Ankara Üniversitesi Eğitim Bilimleri Fakültesi Dergisi, 50(2), 105-125.

Barrows, D., \& Wesson, T. (2000). A comparative analysis of job satisfaction among public and private sector professionals. The Innovation Journal, 5(1), 1-21.

Bright, L. (2005). Public employees with high levels of public service motivation. Review of Public Personnel Administration, 25(2), 138-154.

Bright, L. (2009). Why do public employees desire intrinsic non-monetary workplace opportunities?. Public Personnel Management, 38(3), 15-37.

Büyüköztürk Ş. (2018). Sosyal bilimler için veri analizi el kitabı istatistik, araştırma deseni SPSS uygulamaları ve yorum. (24. Baskl). Ankara: Pegem Yayıncılık.

Caz, Ç. (2018). Açık liderlik ile örgütsel sinizm ilişkisi ve işgören performansina etkisi: Spor eğitimi veren yüksekögretim kurumları üzerine bir uygulama. Doktora Tezi. İstanbul: Marmara Üniversitesi.

Coşkun, S. (2015). Kamu hizmetleri motivasyonu kuramı: bir literatür taraması. Ekonomik ve Sosyal Araştırmalar Dergisi, 11(1), 61-74.

Crewson, P.E. (1997). Public-service motivation: Building empirical evidence of incidence and effect. Journal of Public Administration Research and Theory, 7(4), 499518.

Çınar, O., Yavuz, S. ve Aslan, İ. (2012). Akademisyenlerin internet bankacıllğı hakkındaki tutum, düşünce ve davranışları: Erzincan üniversitesi örneği. Selçuk Üniversitesi IIBF Sosyal ve Ekonomik Araştırmalar Dergisi, 12(23), 103-124.

Frederickson, H. G., \& Hart, D. K. (1985). The public service and the patriotism of benevolence. Public Administration Review, 45(5), 547-553.

Forest, V. (2008). Performance-related pay and work motivation: theoretical and empirical perspectives for the french civil service. International Review of Administrative Sciences, 74(2), 325-339.

Jurkiewicz, C.L., Massey, T.K., \& Brown, R.G. (1998). Motivation in public and private organizations: A comparative study. Public Productivity \& Management Review, 21(3), 230-250.

Knoke, D., \& Wright-Isak, C. (1982). Individual motives and organizational incentive systems. Research in the Sociology of Organizations, 1, 209-254.

Li, C. (2010). Open leadership: How social technology can transform the way you lead. (First Edition) Press by A Wiley Imprint, USA: San Francisco. 
Lyons, S.T., Duxbury, L.E., \& Higgins, C.A. (2006). A comparison of the values and commitment of private sector, public sector, and parapublic sector employees. Public Administration Review, 66(4), 605-618.

OECD (2005). Pay-per performance in public administration. Paris: OECD.

Öztürk, Z. ve Dündar, H. (2003). Örgütsel motivasyon ve kamu çalışanlarını motive eden faktörler. Çukurova Üniversitesi İktisadi ve İdari Bilimler Dergisi, 4(2), 5767.

Perry, J.L. (1996). Measuring public service motivation: an assessment of construct reliability and validity. Journal of Public Administration Research and Theory, 6(1), 522.

Perry, J.L. (2000). Bringing society in: toward a theory of public-service motivation. Journal of Public Administration Research and Theory, 10(2), 471-488.

Perry, J.L., \& Wise, R.L. (1990). The motivational bases of public service. Public Administration Review, 50(3), 367-373.

Perry, J.L., Engbers, T.A., \& Jun, S.Y. (2009) . Back to the future? performance-related pay, empirical research and the perils of persistence. Public Administration Review, 69(1), 39-51.

Perry, J.L. \& Hondeghem, A. (2008). Building theory and empirical evidence about public service motivation. International Public Management Journal, 11(1), 3-12.

Piaw, Y, C. \& Ting, L, L. (2014). Are school leaders born or made? examining factors of leadership styles of malaysian school leaders. Procedia - Social and Behavioral Sciences 116, 5120-5124.
https://www.sciencedirect.com/science/article/pii/S1877042 81401101X Erişim Tarihi: 21.12.2020

Polat, M. \& Arabacı, İ. B. (2014). Eğitimde açık liderlik ve sosyal ağlar. Journal of World of Turks/ Zeitschrift für die Welt der Türken, 6(1), 257-275.

Polat, M. (2015). Yöneticilerin açık liderlik özellikleri ve sosyal ăglarl benimseme durumlarının, örgütsel belirsizlik üzerindeki etkileri: Fırat Üniversitesi Örneği. Doktora Tezi. Elazığ: Firat Üniversitesi.

Polat, M., \& Arabacı, İ. B. (2016). Açık liderlik ölçeğinin geliştirilmesi. Kastamonu Ë̆itim Dergisi, 1(24), 79-96.

Prysmakova, P. (2013). Public service motivation in Europe: Testing attitudes toward work motives. Working Paper, Florida International University. http://www.nispa.org/files/conferences/speeches/201304 221128240.Paper_for\%20_presentation_ASPA_Prysma kova.pdf. Erişim Tarihi: 25.12.2020.

Uçar, R. (2015). Illkokul müdürlerinin dă̆ltımcı liderlik davranışlarl ile ögretmenlerin motivasyon ve yaratıcılık düzeyleri arasındaki ilişki (Diyarbakır ili örneği). Yüksek Lisans Tezi. Diyarbakır: Dicle Üniversitesi.

Yazıcıŏlu, Y. \& Erdoğan, S. (2014). SPSS uygulamalı bilimsel araştırma yöntemleri. Detay Yayıncılık, Ankara.

Yıldız, B. B. (2019). Okul yöneticilerinin açık liderlik, örgütsel adalet ve örgütsel erdemlilik algllart arasındaki ilişkilerin incelenmesi. Doktora tezi. İstanbul: Marmara Üniversitesi -İstanbul Sabahattin Zaim Üniversitesi Ortak Doktora Programı. 


\section{Extended Abstract}

\section{Introduction and Research Purpose}

In order to reach 21 st century skills, the competencies of employees in enterprises should be developed and supported in line with predetermined targets. In this context, it is important that the managers of healthcare institutions, healthcare professionals, patients and their relatives act in cooperation to create health services suitable for the society. Today, when the need for work to be done with team spirit is increasing, health institutions need managers who will support and direct the work towards these goals in order to reach the predetermined goals. Since there is no always and everywhere the best method in the management of an institution, it is expected that the managers of health institutions will use their power in the light of their evaluations about the society they are in.

Today, new leadership concepts related to leadership are getting more and more important. One of the most important features expected from leaders is that businesses take the leading role in achieving their goals. Leaders with managerial characteristics assuming leadership roles in health institutions should have many different qualities. Managers with open leadership will be leaders focused on functional management by developing a sincere interpersonal bond in healthcare institutions. In this context, the expression of openness in many different leadership types is an important feature that leaders should have (Polat and Arabac1, 2014: 36).

Work motivation is seen as the main determinant of individual and corporate performance. Motivated employees are among the basic elements for the quality service delivery of the institutions. In this context, managers of healthcare institutions attached importance to the factors that affect the motivation of employees. The Public Services Motivation (PSM) theory aims to approach the subject in detail and consistently. This theory tries to harmonize different motivation factors with each other. In other words, the theory explains why employees in public institutions have different levels of job motivation by evaluating them together with their internal and external factors (Anderfuhren-Biget et al., 2010: 213).

In this study, the relationship between open leadership and public service motivation, which is a type of leadership based on managerial openness, is emphasized. First of all, a conceptual framework is drawn about open leadership and public service motivation. Then, information about the practice in a public hospital operating in the health sector was given. In the conclusion part, the results about the usability of open leadership by managers in the health sector and its effects on employee motivation are mentioned.

\section{Metodology}

The main purpose of this study is to determine the effect of health workers' perceptions of open leadership on public service motivation. In addition, it was aimed to make the necessary arrangements to provide a working environment within the framework of open leadership principles as a result of the suggestions to be made by creating the necessary awareness in this direction. The research hypotheses;

H1: Health workers' perceptions of open leadership affect their public service motivation levels.

H2: Open leadership perceptions differ according to occupationaldemographic information.

H3: According to occupational-demographic information, motivation levels of public service differ.

Research universe is composed of a province in Turkey's connected to public health workers who work in a hospital. The number of personnel working in the institution at the time of the research is 746 . Within the scope of the research, 350 people could be reached with the simple random sampling method with a 5\% sampling error. 242 of the questionnaires distributed were returned due to the people not wanting to participate in the questionnaire, being on leave or working in the watch system. Since 13 of these questionnaires were filled incompletely and incorrectly, they were excluded from the evaluation and 229 of the remaining questionnaires were deemed suitable for analysis. The questionnaires were distributed and collected by hand after obtaining official written permission from the institution where the research will be conducted. Completely filled data were taken into statistical evaluation and while evaluating the data, frequency distribution, percentage, t-test, Anova and Pearson correlation tests were used.

Personal information form, open leadership scale and public service motivation scale were used to collect data. Open Leadership Scale: This Scale developed by Polat and Arabaci (2016) was used to measure the open leadership perceptions of the participants. The scale consists of three parts and a total of 23 statements. For this study, the cronbach alpha value of the scale was determined to be 0.895 . According to these results, the scale is highly reliable. Public Service Motivation Scale: This Scale developed by Aydın et al. (2017) was used to measure the level of public service motivation of the participants. The scale consists of three parts and 19 statements in total. In this study, the cronbach alpha value of the scale was determined as 0.653 '. According to these results, the scale is quite reliable. A 5-point Likert type scale was used in the expressions in the relevant surveys.

\section{Results and Conclusions}

According to the findings obtained from the research; Open leadership perception has a significant positive effect on public service motivation. In addition, the percentage of open leadership explaining the public service motivation was determined as $35.7 \%$. In other words, the increase in the perception of open leadership also increases the motivation of public service. Looking at the research findings, it was seen that the levels of open leadership and public service motivation in the institution were at a high level. As a result of the research, the open leadership average of the employees is 3.80; public service motivation average was found to be 4.13 . It can be said that this finding is higher than the evaluation interval determined by Çınar et al. (2012).

It was also found that there was a partial difference in the perception of open leadership and public service motivation according to the professional-demographic demographic information of the participants. In the study, it was observed that male participants had a higher average than female participants. Again, it can be said that the level of open leadership perception of administrative staff is higher than physicians and non-medical health personnel. In addition, the perceptions of employees with a postgraduate education level about open leadership were found to be higher than those of employees with other education levels.

It can be said that the level of public service motivation of nonmedical health personnel is higher than that of physicians and administrative personnel. In addition, it was concluded that employees with a working period of 0-3 years in the profession have higher levels of public service motivation than other groups. In other words, as the working time increases, the level of public service motivation decreases.

According to these results; The status of the hypotheses (at the significance level of 0.05 ) is as follows.

- H1: The hypothesis that "perceptions of healthcare professionals regarding open leadership affect their public service motivation" was accepted.

- H2 The hypothesis that "open leadership perceptions differ according to occupational-demographic information" was partially accepted.

- H3 The hypothesis that "levels of public service motivation differ according to professional-demographic information" was partially accepted.

The study is expected to guide other future studies. Since the research is conducted only on health sector employees, its application to other sectors will contribute to the development of the subject. This study was applied to health professionals working in a public hospital in a province in Turkey. In order to make generalizations about all healthcare workers, the implementation of a similar study to healthcare professionals working in the public and private sectors in other provinces will contribute to the subject. 
Ek-1 Etik Kurul İzni

T.C.

MUS ALPARSL.AN ONIVERSITESI

BILIMSEL ARASTIRMA VE YAYINETIGI KURULO

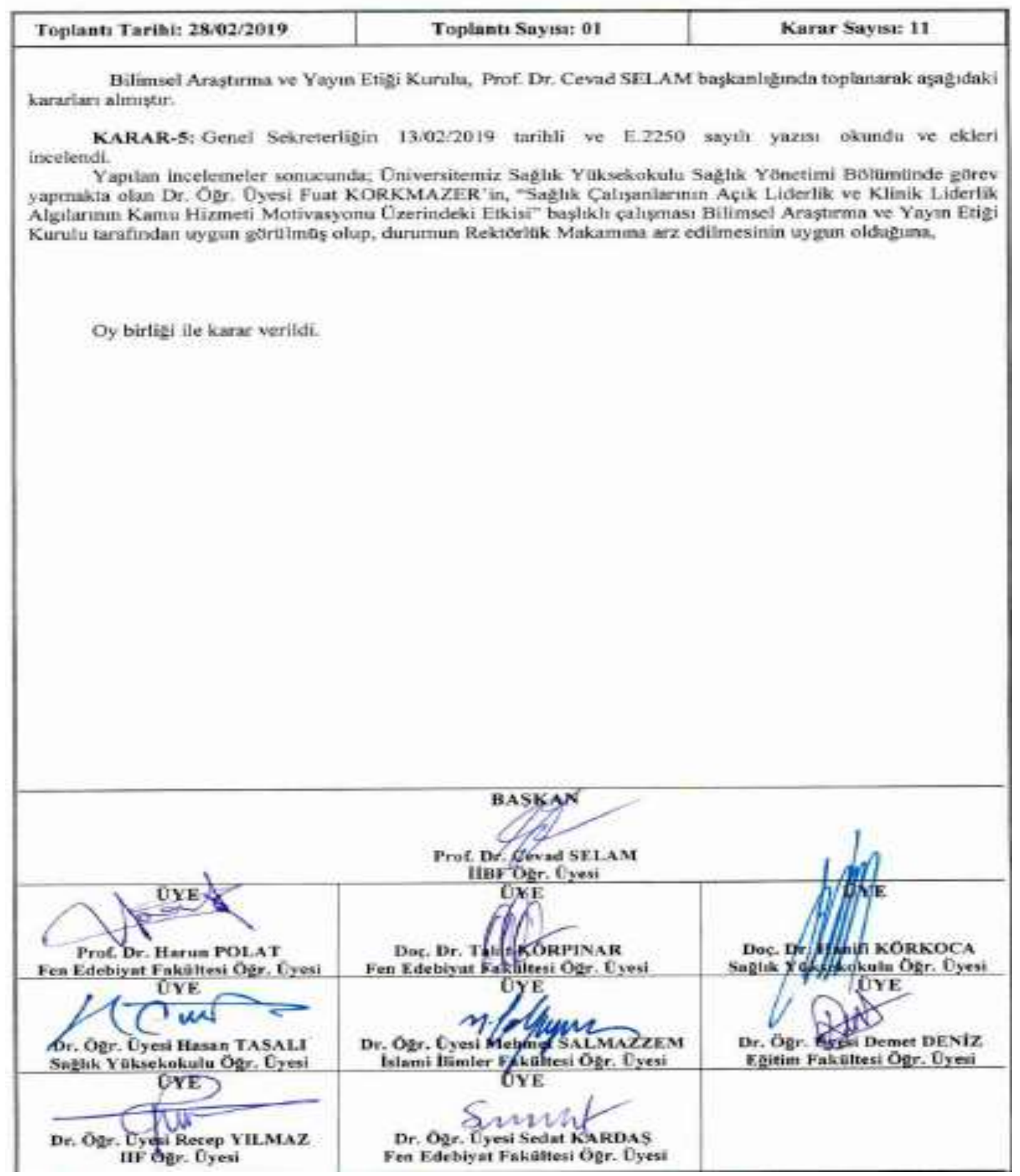

